\title{
Palestinian Postmemory
}

\section{Melancholia and the Absent Subject in Larissa Sansour's In Vitro, Saleem Haddad's “Song of the Birds," and Adania Shibli's Touch}

\section{Layla AlAmmar}

\section{Introduction}

The dystopic film In Vitro, by Palestinian artist and filmmaker Larissa Sansour, takes place in a bunker many years after an eco-disaster in the West Bank city of Bethlehem. The protagonist, Alia, is a clone that was created after the traumatic event but has been implanted with the memories of those who lived through it. Consequently, she bears the effects of the trauma as a transgenerational transmission: "I was raised on nostalgia ... My own memories replaced by those of others ... The pain these stories cause are two-fold because the loss I feel was never mine." Calling her existence a "congenital exile," she argues that constant recounting of traumatic history reduces it to "symbols and iconography," such that her very being becomes "a liturgy chronicling our losses." ${ }^{1}$ With this film, Sansour argues that the Palestinian identity is "an identity that's in trauma," whereby individuals are raised on memories of the past to maintain resistance for a possible future of self-determination, which, in turn, can void the present of meaning. ${ }^{2}$

In the film an eco-disaster stands in for the traumatic events that form the backdrop of the majority of Palestinian art and literature, namely the 1948 Nakba and the 1967 Naksa. ${ }^{3}$ These historic traumas loom large over artefacts of Palestinian cultural expression, solidifying a sense 
of collective identity in a present reality of fragmentation and displacement. Furthermore, nostalgic memories of a pre-1948 Palestine can sustain resistance and motivate return to a past unity. In Vitro deftly interrogates the goal of recovering a long-lost "golden age." In addition to the fact that the new generation was created as clones of those who experienced the catastrophe, the bunker also contains a large orchard planted using seeds salvaged before the land became uninhabitable. Consequently, the older generation attempts to re-create their past existence while neglecting to consider the sense of alienation this engenders in the new generation. This causes a fundamental temporal disconnect between the two generations: a skeptical Alia says, "What we are doing here will not restore the past," to which Dunia, who lived through the disaster, replies, "There is no need to. The past is still there, as intact as ever." In other words, while Alia desires leaving history behind in order to fully embody the present, thereby allowing for some viable future, Dunia asserts that the present does not exist in any meaningful way because they all remain locked in an atemporal sphere of trauma. Thus, the film cogently illustrates the burden of postmemory while extending the paradigm to contexts where trauma is not strictly past but remains present. Consequently, it shows how repeated activation of traumatic histories, and refusal to fully work through them, can lead to a state of transhistorical absence and suspended identity formation.

This article argues that Sansour's In Vitro, Saleem Haddad's short story "Song of the Birds," and Adania Shibli's novella Touch present a uniquely Palestinian postmemory, or what I call a postmemorial absence, which critiques the viability of a future when individuals feel trapped by memories of a traumatic past that prevent a meaningful present from materializing. I argue that these works further invite the question of a Palestinian identity that moves beyond the 
Nakba and what form such an identity might take. The first section discusses how Haddad's and Sansour's works exemplify the burden of collective memory, using the medium of science fiction to explore spatial imaginaries and the precarity of the Palestinian present. The second section illustrates how Shibli's Touch constitutes a powerful imagining of an identity unanchored to a collective traumatic past, whereby severing the inter- and transgenerational traumatic link is attempted. Her work, through its experimental form and style, suggests that negation of subjectivity—a breaking down to build anew—may be necessary to realize an identity unencumbered by past trauma.

\section{The Burden of Collective Memory}

They nurse us on memories formed before us and raise us only for times to come.

Palestinian-Lebanese writer Saleem Haddad's "Song of the Birds," like all the short stories in the collection Palestine +100 , takes place in 2048 , or one hundred years after the Nakba. This historic event, which in Arabic means "catastrophe," was one where more than 700,000 people, or half of prewar Palestine's Arab population, were compelled to flee their land and homes when the State of Israel was created. ${ }^{4}$ Much of the exodus settled in refugee camps in neighboring countries while roughly a quarter remained inside the new State as "internal refugees." ${ }^{\text {In }}$ addition, around 66 percent of the population fled to the semi-autonomous territories of the Gaza Strip and West Bank. ${ }^{6}$

Haddad's story is set in Gaza City where the beach is filled with sunbathers and "cheesy music blasting from the drone speakers in the sky." It is a city of beachfront hotels, "quaint cafés and vintage furniture shops" (14), running hot water and nonstop electricity. It is, in short, 
not a Gaza anyone in the present-day would recognize. As it stands, Gaza is a city under siege. It is a place of fences and walls, where protesters regularly fling themselves into the path of Israeli snipers ranging the perimeter. According to the Guardian article "A Suicide in Gaza," which Haddad cites in a footnote as an influence, after more than a decade under siege, the two-millionstrong population "find themselves without work, their economy killed off, without the bare essentials for decent life - electricity or running water — and without any hope of freedom, or any sign that their situation will change."8

As "Song of the Birds" takes place in a world of biotherapeutic bandages that disintegrate as they heal, robo-cleaners, and teaching holograms, the reader is led to believe that this prosperous setting is the result of a long-desired liberation. However, what appears to be an idyllic existence quickly begins to unravel. As in the reality relayed by the Guardian piece, there is "a spike in teen suicides" (5) across the city in Haddad's tale, one of whom is eighteen-yearold Ziad, the brother of the story's protagonist, fourteen-year-old Aya. Ziad hanged himself the year before and has now begun to appear in her dreams to convince her that the Gaza they live in is a simulation concealing the actual, ravaged city. The siblings were born in the simulation, and the only escape is to commit suicide as he and other teenagers have done.

The despair Ziad feels, and which he transmits to Aya, is attributed to the weight of collective memory within which they grew up. In Cultural Memory and Early Civilization, Jan Assman delineates two types of collective memory: communicative and cultural. The former is transmitted over three or four generations and deals primarily with biographical information, while cultural memory descends into the realm of symbols, myths, and the construction of "a connective structure of common knowledge and characteristics."9 Aleida Assman extends this 
theory into four memory formats: individual and social memory are communicative and embodied while political and cultural memory "are mediated ... and need to be re-embodied" as they are "founded on durable carriers of symbols and material representation." 10 In this way, she sees communicative memory as intergenerational, signifying a vertical, often familial link, while cultural memory is transgenerational or horizontal, carrying affiliative qualities that allow it to transcend the scope of persons linked to the original memories. Identities, both individual and collective, are constituted by collective memory: Aleida Assman asserts that "groups define themselves by agreeing upon what they hold to be important, to which story they accord eminence, which anxieties and values they share." ${ }^{11}$ But how is identity formation affected when the collective memory, and thus the collective identity, is predicated on a historic collective trauma? What does it mean to have an identity formed, as Sansour says, in trauma?

My reading of "Song of the Birds," In Vitro, and Touch shows that they illustrate a postmemorial absence, which deviates from Marianne Hirsch's conceptualization of postmemory by incorporating Dominick LaCapra's theory of absence and loss to produce a state of suspended identity formation. I argue that the historic trauma of the Nakba has been transformed, via the structure of postmemory, into a state of absence for modern-day Palestinians. Moreover, this condition of postmemory is complicated by the fact that the Palestinian cause remains unresolved, resulting in a futile situation that has assumed the transhistorical, foundational, and atemporal aspects of absence, thus finding parallels in Freudian melancholia. I argue that Palestinian postmemory has a character distinguishing it from the historical context that underlies Hirsch's important study. Her work focuses on cultural artefacts produced following the Holocaust, and consequently, there is a temporal distinction between the work and the 
historic traumatic event it seeks to represent. This is not the case in the Palestinian context, where the trauma is not confined to the past but remains a living, breathing wound. According to Rosemary Sayigh, "The Nakba is not merely a traumatic memory, but continually generates new disasters, voiding the present of any sense of security, and blacking out the future altogether." 12 This sense is particularly heightened for Palestinians in the besieged Gaza Strip or the occupied West Bank where life is lived in the long pause of trauma. Indeed, while drafting this article in the summer of 2020, social media and news outlets reported an increase in suicides among Gazans, citing despair over the future, continued Israeli blockades, and poor Hamas governance as main causes. The news was also dominated by Israel's West Bank annexation plans, which met with international opposition. ${ }^{13}$

Under the paradigm of cultural memory, collective historic trauma proves to be a potent rallying point, both for solidifying collective identity and to further ideological and political ambitions. Cultural memory, through its repetitions, rituals, and reliance on symbols and metaphors, has the power to transform historic trauma into foundational myths. In his introduction to Writing History, Writing Trauma LaCapra defines a "founding trauma" as "trauma that is transformed or transvalued into a legitimating myth of origins." 14 Similarly, in Dark Continents Ranjana Khanna builds on Volkan and Kakar's notion of "chosen trauma" as "an event ... often employed by groups to consolidate a sense of collective identity. . . . The event qua event, takes on a particular resonance for the history of the people, their most deeply felt cultural affiliations and anxieties, and collective symbols of a community."15

Palestinian literature and art are rich in nostalgic renderings of a pre-1948 existence. 
Carol Bardenstein, in her analysis of the Palestinian diasporic lexicon, notes the particular use of the lemon, olive, and fig tree as "metonymic fragments of the homeland from sites of Palestinian dispersion." 16 In reference to the Nakba, she stresses the symbolic use of the orange as one of these fragments that have acquired "emblematic status in the process of their being repeatedly mobilized and circulated"- due, in no small part, to Ghassan Kanafani's The Land of Sad Oranges (1963). ${ }^{17}$ The repeated activation of such symbols in cultural expression reinforces a collective identity and link to the homeland, but it also serves to trigger the traumatic memory of having that homeland seized or being compelled to abandon it. This traumatic weight then dominates the transmission of memories, both through and across generations. In The Generation of Postmemory Hirsch asserts that "collective historical trauma . . . would certainly inflect these schemas of transmission. Both embodied communicative memory and institutionalized cultural memory would be severely impaired by traumatic experience."18 This inflection takes the form of postmemory, which she defines as "a structure of inter- and transgenerational transmission of traumatic knowledge and experience. It is a consequence of traumatic recall but . . . at a generational remove." 19 The original trauma in the texts underlying my analysis is the 1948 Nakba, which has become a foundational basis for Palestinian identity. In other words, an individual grows up "dominated by narratives that preceded their birth, whose own belated stories are evacuated by the stories of the previous generation shaped by traumatic events that can be neither understood nor recreated."20

In "Song of the Birds," Ziad recognizes and resents this burden of collective memory, saying, "These cached memories wrap themselves around us like a second skin" (11). "Cached" is a unique and provocative term. The computer jargon fits with the sci-fi framework in which the collection operates; however, it also carries derogatory connotations that create friction when considered against the "rose-tinted memories" (11) of the older generation. Digitally, cache memory refers to what are essentially junk files, and users are often encouraged to clear cache data for their devices to operate more efficiently. Consequently, Haddad suggests that these collective traumatic memories not only imprison successive generations, but they also weigh 
them down and prevent individuals from functioning as well as they could. This further suggests that severing the link to those memories might be necessary before the future can have any meaningful viability. Indeed, in In Vitro, Alia makes this point to Dunia when she says, "Perhaps a loss of memories is essential to starting over."

Collective grief over a shared traumatic past gestures to collective melancholia. In "The Ego and the Id" (1923) Freud conceives of melancholia as a kind of self-constitution whereby the subject creates a new object within the ego to mitigate the pain of loss. However, through overidentification, the ego then itself becomes an object to which the id directs its love, resulting in an ambivalent emotional response. ${ }^{21}$ Furthermore, the death instinct can take up residence in the superego as a critical agent that directs hostile attacks against the ego. In extreme cases, this can lead to suicide as the ultimate form of self-aggression. ${ }^{22}$ Despite the melancholic despair Ziad displays in Haddad's story, and which is underlined by anecdotal evidence in articles such as the Guardian piece, suicide here is reoriented and portrayed as a form of resistance against the oppressor rather than the surrendering end of the melancholic.

Of note in Freud's essay, and what distinguishes it from his original concept of mourning and melancholia, is the way he subordinates melancholia as an unavoidable step in the mourning process. ${ }^{23}$ Consequently, working through grief can only be accomplished by first subsuming the other into the structure of one's own identity, a form of what Tammy Clewell calls "preserving the lost object in and as the self."24 This leaves conceptual space for a prolonged process of mourning, or indeed one that resists completion entirely. Central to Freud's early theories of mourning and melancholia is the notion of a self primarily constituted by narcissism. In "On Narcissism" (1914) he goes so far as to assert that object-love is little more than a projection of 
self-love, arguing that the former "displays the marked sexual overvaluation which is doubtless derived from the child's original narcissism and thus corresponds to a transference of that narcissism to the sexual object." 25 This theory implies that we do not love others for their unique separateness, but rather that we love the part of ourselves that we have invested in them and that is subsequently reflected back to us. Consequently, when the object departs, we are not mourning them so much as we mourn the part of ourselves that we invested in them. Thus, melancholia, as a kind of unresolved mourning, involves an internalization of the other, wherein the object of grief is maintained within the self because relinquishing it would translate to a loss of ego. ${ }^{26} \mathrm{In}$ the case of Freud's melancholic, the lost object is generally conceived of as an individual, a lost loved one; however, Freud concedes that grief could also arise due "to the loss of some abstraction which has taken the place of one, such as one's country, liberty, and ideal." ${ }^{27}$ If the melancholic maintains the object of grief because relinquishing it would result in a loss of ego, does it then follow that on a collective level this would translate to a risk of attenuated cultural identity? In other words, can we read, in the melancholic narratives of certain communities, a refusal to work through historic traumas entirely because doing so would result in a loss of collective identity? And how is this supposition affected by cases where the trauma is not past but remains present?

On a collective level, melancholic observance, as an act of remembrance, assumes politico-ethical significance. LaCapra sees remembrance as integral to a healthy process of grief, emphasizing that socially engaged memory-work in particular allows a person "to distinguish between past and present and to recognize something as having happened to one (or one's people) back then that is related to, but not identical with, here and now." 28 Sam Durrant would 
agree, viewing melancholia as an ethical commitment that marks "a refusal to acknowledge what others see as the more immediate political concerns of the present." 29

However, this is precisely the complication that arises when considering LaCapra's and Durrant's theories of collective grief, and it is one that epitomizes much of postcolonial studies' engagement with trauma. Both scholars firmly situate trauma in a foreclosed past that, according to them, is fundamentally irretrievable and unrepresentable. In other words, it is possible to write about the Holocaust or North American slavery, for example, but it is not possible to access the moment of the negation of humanity (the original traumatic event) that made those histories possible in the first place. Durrant would argue that the same is true in the Palestinian context, that negation of the humanity of the Other is at the root of any collective trauma - and indeed this is the implicit argument behind Jean-Francois Lyotard's Heidegger and "the Jews," which I discuss in the following section. And while that may be the case (though such an argument brings with it a host of homogenizing and humanist problematics that are beyond the scope of this article), the fact remains that the "founding trauma" or events mentioned above are bracketed in time. I do not seek to place collective traumas, past or present, in a hierarchy. Sorrow is not a competitive sport, and it goes without saying that racism and anti-Semitism persist and (re)produce their own real trauma. However, in the case of Palestine, the founding traumatic event is not situated in a closed past but is ongoing; in the context of Haddad's short story, Sansour's film, and Shibli's novella, the backdrop is one of historic and current trauma. The pain and injustice are not relegated to some dark past but constitute a live wound in the here and now. Both postcolonial and trauma studies tend to focus on the past and future-recovering yesterday so as to engineer a more just tomorrow-while neglecting to fully contend with a 
present that is the product of the former and may preclude the latter. My readings reorient this focus, dissecting the past while remaining fully grounded in the present and eschewing what I see as naive, and largely empty, redemptive promises for the future.

Science fiction proves to be a fruitful genre for the Palestinian context by allowing for the creation of spatial imaginaries that interrogate the notion of a reified place and temporal linear progression. It allows for the dramatization of the ephemeral homeland Palestinians have had to create in and from their memories in addition to highlighting the precarious nature of their current state. Haddad asserts that "Palestine is a rich canvas for science fiction: . . . where tools of subjugation, occupation and resistance are experimented and used." 30 This conceptualizing of Palestine as a place of experimentation parallels Sansour's film, which in Arabic is titled alMukhtabar or the Lab. However, the English title captures the notion of a suspended identity much more vividly. As Dunia tells Alia, "It is conflicting to be engineered from the remains of those we left behind. You were created, but you are still trapped in the womb."31 Speaking to this, Sansour notes that "science fiction works formally for the Palestinian predicament because our identity is suspended between the past and the future. The Palestinian present is an odd space, a limbo." 32 Alia argues that constant recounting of traumatic history transforms the present into "a void" or state of melancholic suspension between the past and future from which she cannot escape.

Here Alia is speaking the language of LaCapra, who in the late 1990s theorized a concept of absence and loss as it relates to expressions of grief. Loss represents a specific, historic trauma to which not everyone is subject while absence is an atemporal state or nonevent that is transhistorical or structural in nature. ${ }^{33}$ LaCapra asserts that there is a danger in conflating 
absence and loss, which can obfuscate historic losses and "etherealize them in a generalized discourse of absence." ${ }^{34}$ In his view, historic losses demand mourning, critique, and sociopolitical activism; however, when "absence, approximated to loss, becomes the object of mourning, the mourning may (perhaps must) become impossible and turn continually back into endless melancholy." ${ }^{35}$ This is Alia's lament when she speaks of a two-fold loss, one of which is not hers, and how for her generation of clones "the grief we carry is different. Loss fails when it's an abstraction." Thus, she affirms LaCapra's assertion that, "In terms of absence, one may recognize that one cannot lose what one never had."36 If Alia stands in for modern-day Palestinians who have grown up shrouded in memories of trauma they did not experience, then Dunia, as representative of the older generation, acknowledges this: "You have never known anything but absence." And yet she insists that they are all perpetually compelled to harken back to a past that "never was, it only is." This recalls Lila Abu-Lughod's assertion that the Nakba "is not just something of the past. It continues into the present in every house demolished by an Israeli bulldozer, ... with every village divided from its fields by the 'separation' wall, and with every Palestinian who still longs to return to a home that is no more." ${ }^{37}$ Thus, existence becomes an atemporal sphere of postmemorial absence, suspended and unresolved, which finds expression across Palestinian literature and art.

Sustaining collective memory of historic trauma is not simply a symptom of melancholic observance but constitutes an exercise and assertion of agency, to both positive and negative effect. In Haddad's story, Ziad writes in a diary entry, “There is an oral tradition of grandparents passing on their stories of Palestine, which helps keep Palestine alive" (9). In other words, memories serve as an act of resistance against the physical and symbolic suppression of voices, 
particularly in cases of continuing coloniality, oppression, and effacement, such as that faced by Palestinians in the Occupied Territories and across the diaspora. This pushes back against LaCapra's argument regarding the futility of representations as vehicles that reach back to a trauma that is fundamentally inaccessible. Given my argument of modern-day Palestinian identity as one that is suspended in an atemporal traumascape, we may view Palestinian cultural artefacts, such as literature, not as attempts to represent historic trauma and its legacies, but rather as acts in and of themselves. Thus, "keeping Palestine alive" not only constitutes a defense against total erasure but also provides incentive to continuing demands for justice and restitution. In the final chapter of Postmemory, Hirsch analyzes Ghassan Kanafani's Returning to Haifa (1970) where a Palestinian couple, Sa'id and Safiyya, returns to the home they abandoned twenty years prior when the Haganah (a Jewish paramilitary organization that later formed the core of the Israeli Defense Forces) launched an attack on Haifa in April 1948. Fleeing the chaos, the couple left behind their infant son Khaldun where he was adopted and raised, as Dov, by the couple who took over the property. Throughout the journey to the house and during their visit, Sa'id catalogues the violent sense of being "out of time" as he is confronted with the different inhabitants roaming the streets, the toponymicide where road names have been replaced with Hebrew ones, as well as the changes to his home. Bardenstein, in discussing the novella, argues that this diasporic anachronism does not represent "being 'out of time' or 'in time' or history, but the perception and sensibility of living in and being shaped by multiple time frames simultaneously." ${ }^{38}$ This sense of simultaneous (em)placement comes to light at the end of the visit when Sa'id tells the other couple that they can stay a while in his house because, as Hirsch says, "It is his house, and he imagines that his son Khalid [a fedayeen or resistance fighter] will 
help recover it." 39 She goes on to argue, "Memory serves a future of armed struggle and resistance here ... and in a context in which the conflict continues and resolution cannot yet be envisioned, return serves the cause of legal and moral claims of recovery." 40

In Sansour's film, the inhabited space is an underground bunker populated by humans and a large orchard, all of which have been engineered from DNA salvaged prior to the disaster that made the land uninhabitable and decimated the population. The bunker is a liminal space, a place of refuge. Thus, it is a temporary solution to Palestinian displacement, with Dunia insisting they will one day reinhabit the land. Consequently, memory in this case also serves the cause of return and recovery. However, Haddad's "Song of the Birds" reveals a bleaker and more sinister situation. The simulation of Gaza is a literal and metaphorical "fake place" where time and space —and hence, reality—lack ontological meaning. Furthermore, Ziad tells Aya that in order to construct this simulacrum, the Israeli authorities "harnessed our collective memories, creating a digital image of Palestine" (14). Thus, they engendered a kind of "right to digital return" (15), which not only makes a mockery of the "right of return" enshrined in UN General Assembly Resolution 194, ${ }^{41}$ but, in fact, constitutes "a new form of colonization" for which Ziad says they must "develop new forms of resistance" (14). Therefore, the overarching message of the story becomes not only a condemnation of the burden of collective memory but also a warning as to the danger that perpetual remembrance can present.

\section{The Absent Subject}

Would our personalities have been different without this weight inside our souls?

-Aya's father, "Song of the Birds" (17)

If Haddad's and Sansour's works poignantly illustrate the burden of postmemory and interrogate 
the possibility of an identity that moves beyond historic trauma, Palestinian author Adania Shibli's Touch (2003 [2010]) engages this burden in inventive ways. The novella uses narrative devices that keep the reader in a state of alienation and melancholic suspension. In this way, the narrative becomes performative of postmemorial absence. However, I argue that it also performs the limits of subjectivity — through language and form - in an attempt to portray an identity that moves beyond endless recounting of traumatic histories. An identity, in other words, unencumbered by the structure of postmemory.

The novella's disjointed narrative resists closure. The text is divided into five chaptersColors, Silence, Movement, Language, and The Wall—which, aside from the final one, are further split into eight subsections. The plot moves laterally across these chapters, unveiling incidents and worrying over others without making concerted efforts toward eventual coherence. The plot, such as it is, concerns the unnamed, youngest daughter of a large family residing in an unnamed village (assumed to be in the West Bank) at an unstated point in time (though the briefest of references to the Sabra and Shatila massacre place it in and around 1982).

The book was originally written in Arabic, thus implying a local/regional audience familiar with the social, cultural, political, and historical context in which it was produced (and to which it speaks). With the English translation, the implied readership is Western and not necessarily familiar with the context - though there are bilingual Arabs who prefer to read in English or readers who do not understand Arabic but are nevertheless familiar with the region and its history. The translation is faithful to the original, with only minor deviations. No attempt is made to gloss the text. Consequently, it can be assumed that what was intended for an Arabicspeaking audience holds true for the English-speaking one. 
The novella explores the limits of subjectivity by attempting to negate the personhood of its characters, suggesting that moving beyond postmemory may require an initial breakdown of subjectivity. In this way, it also highlights the perennial Otherness and resultant futile empathy with which Palestinians are often faced. In a traditional narrative, subjectivity serves as a vehicle for empathy, providing the reader with fully realized, well-rounded subjects to whom they might relate. This subjectivity is conferred by the allocation of names, patronyms, unique characteristics, personal histories, and physical descriptions. Such attributes allow for the subjects to be identified with by the reader. The assumption is that this identification promotes the transcendence of differences and, potentially, cross-cultural solidarity. The transaction is one in which the other is brought into the self, experienced as though it were the self. The risk here, particularly with trauma narratives, is overidentification and possible appropriation of the subject's story, the ultimate danger being that the reader assumes a kind of surrogate victimhood. According to Carolyn Steedman's "Empathy Theory," the self becomes articulated "through the use of someone else's story of suffering, loss, exploitation, pain." 42 She goes on to note that "when ... we are sublimely aware of the harmony of our reactions with those of the person we are sympathizing with, it seems necessary ... that he or she who tells the harrowing tale is diminished by having that story to tell; and is subordinated in the act of telling." ${ }^{\prime 4}$

Durrant, in his discussion of the novels of J. M. Coetzee, acknowledges this problem of empathic identification, contending that to "transcend the other's alterity is to efface that alterity, that the act of empathy is the attempt to imagine the other as the same, as another version of the self." 44 This process, at the point of contact, aborts the possibility of any true reconciliation. The other remains an Other, their pain and suffering filtered through the lens of our experiences and 
worldview. I would argue that such identification, while perhaps genuinely moving at the time, is ultimately transitory in nature and unlikely to affect lasting change — either in the reader or in terms of any activism they might subsequently engage in to help prevent such catastrophes in the future.

We can link this limitation of empathy, particularly as it relates to postcolonial narratives, with Lyotard's concept of Forgetting. In Heidegger and "the Jews" he speaks to the familiar notion of a European identity founded on the denial of the humanity of the Other. In this case, he is referring to an initial foreclosure of the possibility of the humanity of the Jews that was necessary for an event like the Holocaust to occur. Furthermore, he argues that this denial occurs outside of time; it is a primary repression of the Other's humanity that "thwarts all representation." ${ }^{45}$ Durrant expands this argument to include the negation of the Other's humanity at the heart of the racism that made slavery possible, noting that it represents "an act of exclusion that has 'pathological' consequences precisely because it introduces an internal exception into the category of the human." 46 The implication of this, narratively speaking, is that conceiving of the Other as a subject becomes impossible because "that which has been radically excluded from the category of the human is not presentable on the same plane of representation." 47

A more productive identification would be one that does not attempt to bring the other into the self but rather the expelling of the self into the other. Durrant calls this process "abjection" whereby "instead of gaining imaginative access to the experience of another subject, one experiences a radical loss of subjectivity, an 'experience' ... that approximates ... the experience of being other." In this way the other is not imagined as another version of the self; instead, the self is evacuated and "precipitated toward the realm of the inhuman." 48 This 
repurposes Kristeva's notion of the "abject," which narcissistically focuses on the self's response when faced with the breakdown of the symbolic order or the eruption of the Lacanian Real into our system of meaning. ${ }^{49}$ Durrant reorients this effect toward the act of reader empathy in narratives focusing on subaltern characters, particularly, as in the case of Coetzee, when the writer does not share their subject position. In that vein, Durrant points to Friday and Michael K who are only given first names while the character of the barbarian girl in Waiting for the Barbarians is not given any name whatsoever. He sees this "invisibility as subjects" as indicative of "their extrinsic relation to the narrative's symbolic order, to the socio-linguistic sign system that governs human relations." 50 In other words, this narrative choice seeks to propel the readers outside their sense of self, asking them to inhabit a state of otherness or nonsubjectivity rather than simply imagining the other as an alternate version of themselves.

The case is different for Shibli, who does share the subject position of her characters. And yet, Touch goes to great lengths to dramatize a loss of subjectivity in both form and content in what I contend is an attempt to imagine a Palestinian identity unanchored to past trauma. There are no named characters in the narrative, whether first names or patronyms. The protagonist is alternatively called "the girl" or "the little girl," which I maintain functions as a way of roughly orienting the reader in the disjointed chronology of the story. Family members are labeled rather than named - "the father," "the mother," "the brother"- - and minor characters are also only given descriptive labels - "the neighbor," "the shepherd," and so on. It could be argued that, in lacking names, these characters lack a history. In Arab cultures, names are in themselves archives of lineage and collective history whereby a person's full name comprises a chain of patrilineal descent; the first name is followed by that of the father, which is followed by the grandfather's 
first name and so on. It is not uncommon for Arabs to be able to recite five or six generations back. Furthermore, the surname is at times indicative of geographical origins, such as al-Nabulsi ("from Nablus") or al-Safadi ("from Safed"), which inextricably links the family with a land and history regardless of where they may later settle. Moreover, in Shibli's text, not only is no character named, but none are also claimed in that possessive pronouns are not used when referring to them. They are always "the father" rather than "her father," "the mother" instead of "her mother," which also serves to stylistically sever the intergenerational transmission of history.

This lack of ownership is taken to extremes whereby the protagonist even lacks possession of her own body, with references to, for example, "the other hand" 51 rather than "her other hand." This abjection, or absolute negation of personhood, is more pronounced in the Arabic text, with Paula Haydar's translation occasionally appointing possessive pronouns that are absent in the original. For example, at one point the narrator says, "A little piece of paint got stuck between the nail and the finger, but the severe expression on the face and the two closed eyes were due to the sun ... [translations mine and emphasis added]." 52 The use of the definite article "the" (al in the Arabic) distances the reader; in fact, it urges them to view the character as almost inhuman by disconnecting these features from her self-after all, many entities have eyes, faces, and fingers. This device, which is the default in the original, is at times forfeited in the English version where, as in the example above, "fingernail," "face," and "eyes" are all given the possessive pronoun "her" (11).

Moreover, a fixation on subjectivity is highlighted within the narrative as well—as content in addition to the stylistic forms mentioned above. Following the brother's death (which 
I discuss further below), the mother, in her grief, uses pronouns rather than names-referring to the sisters as "you." Only the protagonist, the girl, is denied the pronoun "you" and instead is referred to as "she," even when the mother speaks to her (62). This distance from the mother is reiterated in later scenes, leaving the girl in a state where "her throat filled with the loss of language mixed with the loss of being included in the pronoun you" (63). The wording here is clearly melancholic: the lost object has been swallowed but remains suspended in the throat, unable to be fully incorporated or spat out (introjected). In the 1980s, Nicolas Abraham and Maria Torok extended Freud's arguments on the process of grief, agreeing that it involves the internalization of the lost object, which they categorize in two ways: introjection and incorporation. The first is a process of "normal" mourning whereby "language acts and makes up for absence by representing, by giving figurative shape to presence." 53 In other words, language is the compensation for loss. On the other hand, incorporation is an "inexpressible mourning" where the loss is denied and the other is "swallowed and preserved" along with "the actual or supposed trauma that made introjection impracticable." ${ }^{54}$ Consequently, I maintain that this lack of subjectivity, this absence of self, in Shibli's text reflects a deep-rooted sense of alienation within representational systems. It is the unrecoverable loss, the postmemorial absence, for which there is no substitute and that gives rise to the melancholia permeating the text.

The achronological temporality, to borrow Durrant's term, of the narrative is another way in which Touch engages in a performance of melancholia. The plot is not clearly linear but moves laterally across the narrative, with events threaded into similar points of each chapter. For example, the scenes concerning the boys who come to paint the house (and fall in love with some 
of the sisters) are recounted in sections six of chapters one and two, respectively. The girl's wedding — in what is the present-day narrative — is told in vignettes occupying the eighth section of each chapter except the penultimate one; instead, the end of the wedding is told in the final chapter. Scenes with religious connotation occupy section seven of chapters one and two, respectively. Furthermore, the day the brother's body is returned to the family home is a scene that the girl revisits and reconstructs later in the narrative. The first we learn of it is in the fourth section of chapter two; it is then retold in the fifth section of the third chapter with minor details changed and a focus on a separate aspect of the scene, namely the wailing women. The overall effect of this narrative style is that events seem suspended with the occasional looping to return to certain scenes. This creates a sensation of being unstuck in time, as though events-both traumatic and mundane - are always and forever happening in some atemporal sphere rather than following a causal linearity. Such narrative effects are symptomatic of melancholia itself, highlighting its static state and preoccupation with reconstructing moments related to traumatic loss.

As a fiction writer whose work is often taken as representative of the sociopolitical conditions of my home country, I am wary of reading Shibli's quietly human tale as political allegory. That being said, these nonpersons drifting in the consequences of history appear illustrative of an attempt to render a Palestinian identity that is not always and forever constituted by a historical event. I have argued that the specific loss of the Nakba has been transformed, via the structure of postmemory, into a defining state of absence for modern-day Palestinians, which I believe many writers and artists are attempting to move beyond. However, this condition of postmemory is exacerbated by the fact that the Palestinian cause, in all its manifold dimensions, 
remains unresolved. As per LaCapra's formulation, such cases can lead to the kind of "endless melancholy, impossible mourning, and interminable aporia" that I believe Shibli's narrative dramatizes; it also allows for a sense of futility, whereby "any process of working through the past and its historical losses is foreclosed or prematurely aborted." ${ }^{55}$ Consequently, I read the text's sparse dialogue, pervasive silences, and lack of possessive pronouns as an attempt to sever that generational link of traumatic knowledge, an attempt to exist beyond and outside a history of perpetual (and perpetually recounted) catastrophe. An attempt, in other words, to transcend a condition of postmemorial absence and melancholia.

In State of Siege, the poet Mahmoud Darwish writes, "Only when life gets back to normal again | can we grieve like everyone else over personal matters." 56 In Touch, none of the political touchstones of Palestinian literature are referenced—no mention of the Nakba or the Naksa or the aggressions and humiliations of life under Israeli occupation. In eschewing recounting of historic trauma and the activation of symbolic fragments such as the tree, Shibli opens up space for her characters to express a quintessentially personal grief. The major trauma the family experiences is the death of the brother. The reader is never told how he died; there is no mention of wounds nor is blame assigned to any entity or activity (politically motivated or otherwise) in which he may have been involved. He is simply brought by ambulance to the family home and laid at the mother's feet. Subsequently, the family engages in expected (and healthy) acts of mourning: there is a funeral and prayers at the mosque with the mother exhibiting overwhelming grief (6); the mother directs her misplaced anger toward the surviving children (63); and she eventually comes to accept the death, hanging a large photograph of the brother in the living room (24). In removing the overarching political conflict, which has a 
tendency to obfuscate and, to an extent, homogenize individual experiences, Shibli allows a radically personal story of grief to emerge. The mourning displayed thus serves as a pointed contrast to the melancholic suspension that otherwise characterizes the text.

\section{Conclusion}

My argument in this article has been that, in the Palestinian context, the structure of postmemory has, over generations, transformed historic loss into a foundational state of postmemorial absence with its attendant melancholic affectations of atemporal suspension and object attachment. The young protagonists of Haddad's "Song of the Birds" and Sansour's In Vitro did not live through the traumatic events that led to the collective memories within which they have been nurtured; and so they rebel, displaying a resentfulness toward the older generation's continued veneration of memories of loss and displacement. In doing so through the medium of science fiction, these works of Palestinian cultural expression interrogate the viability of a future in contexts where past remains present.

Shibli's Touch, while also illustrative of a postmemorial absence, goes further by imagining what form an identity severed from inter- and transgenerational trauma might take. The novella innovatively critiques the notion of subjectivity as it relates to melancholia and the virtue of empathic identification itself. The lack of character names and possessive pronouns represent a negation of the self, which dramatizes the difficulty Palestinians face in constructing individual identities that are not constituted by the postmemory of traumatic historic losses. There is a brief reference to the 1982 Sabra and Shatila massacre and an even more oblique reference to the banning of the use of the word Palestine. It could be argued that perhaps this is 
where the novella fails to completely imagine a Palestinian identity unencumbered by a history of displacement and trauma. Had Shibli not included these blink-and-miss-them references, one could almost imagine the narrative taking place in any setting characterized by chronic trauma. Their inclusion seems to suggest that it is not possible to entirely sever oneself from a collective traumatic past.

These works of Palestinian fiction illustrate how individuals inhabit a multifaceted history that extends far beyond their own embodied memories. These works further illuminate the ways in which a complex array of trauma, both past and present, personal and political, can produce a conflicted, suspended, and in many ways absent identity, which may, in turn, lead to what Haddad calls "a haunted existence." 57

Layla AlAmmar is a writer and academic from Kuwait with a master's degree in Creative Writing from the University of Edinburgh. She is currently pursuing a $\mathrm{PhD}$ at Lancaster University, researching Arab women's fiction as archives of traumatic memory. Her debut novel, The Pact We Made (2019), was longlisted for the Authors' Club Best First Novel Award and nominated for the First Book Award at the Edinburgh International Book Festival. Her second novel, Silence Is a Sense, will be published in March 2021. She has written for The Guardian and Arablit Quarterly.

\section{Notes}

1. Larissa Sansour and Søren Lind, dir., In Vitro (Copenhagen: Danish Arts Foundation, 2019).

2. Alexandra Chaves, "Seeing Palestine through the Lens of Science Fiction," The National (2019), https:/ www.thenational.ae/arts-culture/art/seeing-palestine-through-the-lens-of-science-fiction-1.932583.

3. The Nakba (or "catastrophe") resulted in the expulsion of 700,000 Palestinians, or 80 percent of Arab inhabitants of Mandatory Palestine, when the State of Israel was created; see Nur Masalha, Expulsion of the Palestinians, 4th ed. (Washington, D.C.: Institute for Palestine Studies, 1992), 175. The Naksa (or "setback") refers to the displacement of more than 300,000 Palestinians from the West Bank and Gaza Strip after these territories were captured by Israel during and after the Six-Day War (June 5-10, 1967); see Benny Morris, Righteous Victims: A History of the Zionist-Arab Conflict, 1881-2001 (New York: Vintage Books, 2001), 328.

4. Morris, Righteous Victims, 252-58.

5. "Number of Palestinians (in the Palestinian Territories Occupied in 1948) for Selected Years, End Year," Palestinian Central Bureau of Statistics, http://www.pcbs.gov.ps/Portals/_Rainbow/Documents/Pal48- 
POPU-2010E.htm.

6. United Nations, Population and Demographic Developments in the West Bank and Gaza Strip until 1990 (Geneva: United Nations Conference on Trade and Development, 1994), 11, https:/unctad.org/en/docs/ poecdeseud1.en.pdf.

7. Saleem Haddad, "Song of the Birds," in Palestine +100 , ed. Basma Ghalayini (Manchester: Comma Press, 2019), 1. Text references are to this edition.

8. Sarah Helm, “A Suicide in Gaza,” The Guardian, May 18, 2018, https:/www.theguardian.com/news/2018/may/ 18/a-suicide-in-gaza.

9. For more on collective memory, see Jan Assman, Cultural Memory and Early Civilization: Writing, Remembrance, and Political Imagination (Cambridge: Cambridge University Press, 2011), 36.

10. Aleida Assman, "Re-framing Memory: Between Individual and Collective Forms of Constructing the Past," in Performing the Past: Memory, History, and Identity in Modern Europe, ed. Karin Tilmans, Frank van Vree, and Jay Winter (Amsterdam: Amsterdam University Press, 2010), 40-42.

11. Assman, "Re-framing Memory," 38.

12. Rosemary Sayigh, "On the Exclusion of the Palestinian Nakba from the "Trauma Genre," Journal of Palestine Studies 43, no. 1 (2013): 56, https://www.jstor.org/stable/10.1525/jps.2013.43.1.51.

13. See Ali Adam, "Gaza's Young People Turn to Suicide amid Growing Desperation," The National, July 6, 2020, https://www.thenational.ae/world/mena/gaza-s-young-people-turn-to-suicide-amid-growing-

desperation-1.1045005. See also "Israel West Bank Annexation Rejected by European MPs in Letter," BBC News, June 24, 2020, https://www.bbc.com/news/world-middle-east-53139817.

14. Dominick LaCapra, Writing History, Writing Trauma (Baltimore: Johns Hopkins University Press, 2014), xii.

15. Ranjana Khanna, Dark Continents: Psychoanalysis and Colonialism (Durham: Duke University Press, 2003), 14.

16. Carol Bardenstein, "Figures of Diasporic Cultural Production: Some Entries from the Palestinian Lexicon," in Diaspora and Memory: Figures of Displacement in Contemporary Literature, Arts and Politics, ed. Marie-Aude Baronian, Stephan Besser, and Yolande Jansen (Amsterdam: Rodopi, 2007), 23.

17. Bardenstein, "Figures of Diasporic Cultural Production," 24.

18. Marianne Hirsch, The Generation of Postmemory: Writing and Visual Culture after the Holocaust (New York: Columbia University Press, 2012), 33.

19. Hirsch, The Generation of Postmemory, 6 .

20. Hirsch, The Generation of Postmemory, 5.

21. Sigmund Freud and James Strachey, The Standard Edition of the Complete Psychological Works of Sigmund Freud. Vol. 19 (1923-1925): The Ego and the Id and Other Works (London: The Hogarth Press \& The Institute of Psychoanalysis, 1961), 31-35.

22. Freud, The Ego and the Id and Other Works, 52.

23. In "Mourning and Melancholia" (1917), mourning is the act of a conscious mind grieving over a named loss whereas melancholia is an unconscious act of grief over a loss the subject cannot name. In other words, mourning is a healthy process of grief while melancholia is a static and unproductive pathological condition. Mourning comes to an end when the mourner severs emotional attachment to the lost object and is free to re- 
cathect in a new (or substitute) object. See Sigmund Freud and James Strachey, The Standard Edition of the Complete Psychological Works of Sigmund Freud. Vol. 14 (1914-1916): On the History of the Psycho-analytic Movement; Papers on Metapsychology; Mourning and Melancholia and Other Works (London: The Hogarth Press \& The Institute of Psychoanalysis, 1957), 245.

24. Tammy Clewell, "Mourning beyond Melancholia: Freud's Psychoanalysis of Loss," Journal of American Psychoanalytic Association 52, no. 1 (2004): 61, https://journals.sagepub.com/doi/

10.1177/00030651040520010601.

25. Freud and Strachey, On the History, 88.

26. Freud and Strachey, On the History, 247-49.

27. Freud and Strachey, On the History, 243.

28. Dominick LaCapra, “Trauma, Absence, Loss,” Critical Inquiry 25, no. 4 (1999): 713, https://www.jstor.org/ stable/1344100.

29. Sam Durrant, Postcolonial Narrative and the Work of Mourning: J. M. Coetzee, Wilson Harris, and Toni Morrison (New York: State University of New York Press, 2004), 41.

30. Tugrul Mende, "Reimagining Palestine in the Future: An Interview with Saleem Haddad," Open Democracy, https:/www.opendemocracy.net/en/north-africa-west-asia/reimagining-palestine-future-interview-saleemhaddad/?fbclid=IwAR0-x2QlbkEaSRuzfkbM4GKNRGyrjxC0AvlboZFz4-kNctddhQVEy4g4p 1 M.

31. The film's subtitles state "You were born," but the Arabic word khuliqti literally translates to "created."

32. Lindsey Moore, "Suspended between the Past and the Future: Larissa Sansour in Conversation with Lindsey Moore," in Larissa Sansour: Heirloom, ed. Anthony Downey (Berlin: Sternberg Press, 2020), 111.

33. LaCapra, "Trauma," 699.

34. LaCapra, "Trauma," 700.

35. LaCapra, "Trauma," 715.

36. LaCapra, "Trauma," 701.

37. Lila Abu-Lughod, "Return to Half-Ruins: Memory, Postmemory and Living History in Palestine," in Nakba: Palestine, 1948, and the Claims of Memory, ed. Lila Abu-Lughod and Ahmad H. Sa'di (New York: Columbia University Press, 2007), 103.

38. Bardenstein, "Figures of Diasporic," 26.

39. Hirsch, The Generation of Postmemory, 215.

40. Hirsch, The Generation of Postmemory, 215.

41. Article 11 of the resolution (adopted December 1948) says: "Refugees wishing to return to their homes and live at peace with their neighbors should be permitted to do so at the earliest practicable date, and compensation should be paid for the property of those choosing not to return and for loss of or damage to property which, under principles of international law or equity, should be made good by the Governments or authorities responsible." See United Nations Relief and Works Agency for Palestinian Refugees in the Near East, www.unrwa.org/content/resolution-194.

42. Carolyn Steedman, "Enforced Narratives: Stories of Another Self," in Feminism and Autobiography: Texts, Theories, Methods, ed. Tess Cosslett, Celia Lury, and Penny Summerfield (London: Routledge, 2000), 34. 43. Steedman, "Enforced Narratives," 34. 
44. Durrant, Postcolonial Narrative, 27.

45. Jean-Francois Lyotard, Heidegger and "the Jews," trans. Andreas Michel and Mark Roberts (Minneapolis: Minnesota University Press, 1990), 5.

46. Durrant, Postcolonial Narrative, 4.

47. Durrant, Postcolonial Narrative, 7.

48. Durrant, Postcolonial Narrative, 27.

49. Julia Kristeva, Powers of Horror: An Essay on Abjection, trans. Leon S Roudiez (New York: Columbia University Press, 1982), 2-4.

50. Durrant, Postcolonial Narrative, 26.

51. Adania Shibli, Touch, trans. Paula Haydar (Northampton, MA: Clockroot Books, 2010), 2.

52. [Qishratu țalā' șaghira ta 'laqat baina al'ẓfir wa al'șbi', lākina hidatu ta 'bir alwajh wa al'ainain almughlaqatain kānat bisabab alshams ... .] 'Adanīyah Shiblī, Masās (London: Mu'assasat 'Abd al-Muhsin al-Qațtān, 2003), 24.

53. Nicolas Abraham and Maria Torok, "Mourning or Melancholia: Introjection versus Incorporation," in The Shell and the Kernel, trans. and ed. Nicholas T. Rand (Chicago: University of Chicago Press, 1994), 128.

54. Abraham and Torok, "Mourning or Melancholia," 130.

55. LaCapra, "Trauma," 698.

56. Mahmoud Darwish, State of Siege, trans. Munir Akash and Daniel Abdal-hayy Moore (New York: Syracuse University Press, 2015), 63.

57. Saleem Haddad, email message to the author, July 6, 2020. 